\title{
The Compliance-Based Coffee Growers of Bondowoso on Regent Amin Said Husni in the Culture of Madurese Society
}

\author{
Latifatul Izzah \\ Faculty of Humanity University of Jember \\ email: latifatul.sastra@unej.ac.id \\ Singgih Tri Sulistiyono \\ Faculty of Humanities, Diponegoro University \\ email: singgihtrisulistiyono@gmail.com \\ Yety Rochwulaningsih \\ Faculty of Humanities, Diponegoro University \\ email: wulan.psa.undip@gmail.com \\ Dewi Salindri \\ Faculty of Humanity University of Jember \\ email: dewisalindri62@gmail.com \\ Sri Ana Handayani \\ Faculty of Humanity University of Jember \\ email: srianahandayani@gmail.com \\ Jani Januar \\ Faculty of Agriculture University of Jember \\ email: dekanfp_jani@unej.ac.id \\ Neneng Afiah \\ Manyar Senior High School, Gresik \\ email: neneng.afiah75@gmail.com
}




\begin{abstract}
This study discussed the compliance of the coffee farmers particularly in Sumberwringin Bondowoso against the figure Amin Said Husni. The Regent concerns for the fate of the coffee farmers and public welfare in Bondowoso cannot be inseparable from the religious life of the Regent; implementing policies based on the principles of the Islamic religion. This study aimed to answer the question regarding the causes of the emergence of people's compliance with coffee farmers to switch the Arabica coffee plant according to the instructions given by the Regent. This study applied the habitus concept developed by Pierre Bourdieu and sharpened using the Historical Method. The studied population was coffee farmers at district of Sumberwringin (Sukorejo, Rejoagung and Sumberwringin village). This study found that the compliance of the coffee farmers could attract people who originally planted Robusta switched to Arabica Coffee as their Regent's instruction. The compliance of coffee farming communities (majority of Madurese) was hierarchical obedience that became a necessity to be actualized in daily praxis as "normative" binding. The compliance of produce luck to economic conditions as well as improving the welfare of coffee farmers, because the selling price of Arabika is higher than the Robusta coffee.

[Kajian ini membahas tentang kepatuhan para petani kopi Bondowoso khususnya Kecamatan Sumberwringin terhadap sosok Bupati Amin Said Husni. Kepedulian Bupati terhadap nasib para petani kopi dan kesejahteraan masyarakat Bondowoso tidak terlepas dari kehidupan Bupati yang agamis. Melaksanakan kebijakannya berdasarkan kaidah-kaidah agama Islam. Kajian ini bertujuan menjawab permasalahan mengenai: Penyebab munculnya kepatuhan para petani kopi rakyat untuk beralih menanam kopi Arabika sesuai instruksi Bupati. Penelitian ini akan dibedah dengan menggunakan "Konsep Habitus" yang dikembangkan oleh Pierre Bourdieu serta dipertajam dengan menggunakan Metode Historis. Populasi yang dijadikan fokus adalah petani kopi rakyat Kecamatan Sumberwringin (Desa Sukorejo, Desa Rejoagung dan Desa Sumberwringin) Kabupaten Bondowoso. Dari hasil penelitian ini didapatkan informasi bahwa kepatuhan petani kopi rakyat yang semula menanam Kopi Robusta dan beralih pada Kopi Arabika karena instruksi Bupati. Kepatuhan masyarakat petani kopi yang mayoritas etnis Madura merupakan kepatuhan hierarkis yang menjadi keniscayaan untuk diaktualisasikan dalam praksis keseharian sebagai "aturan normatif" yang mengikat. Kepatuhan tersebut menghasilkan keberuntungan terhadap kondisi ekonomi serta meningkatkan kesejahteraan bagi para petani kopi, karena harga jual Kopi Arabika lebih tinggi dari Kopi Robusta.]
\end{abstract}

Keywords: Regent, Coffee Farmers, Madurese Ethnic, Madurese Culture 


\section{Introduction}

PTPN XII as a Large State that owned plantation has pioneered the planting of Arabica coffee (Java Coffee). ${ }^{1}$ The PTPN XII's coffee plantation is a legacy from the colonial era that has continued by the existence of HGU (Hak Guna Usaha) as a right over business management. ${ }^{2,3}$ The success of PTPN XII hrough the international market is inseparable from Arabica coffee plants, so the Ijen plateau controlled by PTPN XII is known as the "Ijen Golden Triangle" region. The area represents the bordering Situbondo regency, Banyuwangi and Jember. This condition results in the decline of smallholder plantations in the area of Bondowoso; one of the plantations locates in Sumberwringin District.

Various efforts have been made by Bondowoso government to intensify smallholder plantations, especially in the cultivation of coffee in order to compete with the sizeable state-owned Plantation (PTPN XII). One of them is by assigning Forestry Department and Plantation Services of Bondowoso regency to foster farmers' progress. Plant commodities that are under the auspices of Bondowoso regency Forestry and Plantation Service include five commodities groups consisting of annual plant, annual crops, and spice plants freshener. However, the commodity prioritized for its current development is Arabica Coffee. Considering that the commodity includes in the group of spice plants freshener as one of the leading commodities at local, regional, and national scopes. In fact ${ }^{4}$, almost in all regions in Indonesia, mainly reviews those that have the topography of the area above an altitude of 700 meters above sea level, people seek coffee plants to be planted plants as their excellent. Likewise, the area in Sumberwringin sub-district, Bondowoso regency, especially Sumberwringin village,

\footnotetext{
${ }^{1}$ Latifatul Izzah and Hairus Salikin, "Feudal Culture in the Ijen Highlands' Poor Society", Jurnal Karsa vol. 24 No. 2, Desember (2016): 174.

${ }^{2}$ Latifatul Izzah, Dataran Tinggi Ijen: Potongan Tanah Surga untuk Java Coffee (Yogyakarta: Jogja Bangkit Publisher, 2016), 38-39.

${ }^{3}$ Latifatul Izzah, dkk., Cluster Kopi Arabika: Produk Primadona Petani Kopi Rakyat Bondowoso (Yogyakarta: Best Publisher, 2018), 2.

${ }^{4}$ Badan Pusat Statistik Kabupaten Bondowoso, 2015, Kabupaten Bondowoso Dalam Angka .
} 
Rejoagung village, and Sukorejo village ${ }^{5}$, Sumberwringin sub-district is one of the sub-districts of 23 sub-districts in Bondowoso with a distance of approximately $27 \mathrm{~km}$ Southeast of the district capital. Geographically, Sumberwringin sub-district locates at an altitude of $800-1200^{6}$ meters above sea level of the which is suitable for growing coffee plants, especially Arabica coffee.

\section{Methods}

This research used habitus concept developed by Pierre Bourdieu $^{7}$ and sharpened using Historical Method ${ }^{8}$. An individual disposition had habitus to perception and response in a particular way against the surrounding environment. Disposition was defined as social experience instilled by the origin environment of the individuals, implanted into the individual from childhood in the family environment as well as in other social groups. ${ }^{9}$ Habitus was conceived by Bourdieu in various ways, namely (1) the trends that empirically act in particular ways, (2) as motivation, aspirations, and feelings, (3) as behaviors ingrained, (4) as the practical skills and social skills, and (5) the aspirations and expectations with regard to change of life and career.

According to Pierre Bourdieu, habitus is merely proposing what people should think and what should they choose to do. In making a choice, the actor uses in-depth consideration by consciousness, though the process of making this decision reflects the active involvement of the habitus. Habitus provides the principles by which the actors make choices and choose a strategy that will be used in social life. In essence, "people are not stupid, although they are also not entirely rational". That

\footnotetext{
${ }^{5}$ Profil Desa dan Kelurahan Kabupaten Bondowoso, 2015, Potensi Desa dan Kelurahan Desa Sukorejo Kecamatan Sumberwringin.

${ }^{6}$ Izzah, dkk., Cluster Kopi Arabika, 3.

${ }^{7}$ Philip Smith, Cultural Theory: An Introduction (Oxford \& Massachusetts: Blackwell Publishers, 2001), 133-135.

${ }^{8}$ Louis Gottschalk, Mengerti Sejarah, Terjemahan Nugroho Notosusanto, (Jakarta: UI Press, 1993), 18.

9 Moh. Hefni, "Bhuppa'-Bhabhu'-Ghuru-Rato (Studi Konstruktivisme Strukturalis tentang Hierarkhi Kepatuhan dalam Budaya Masyarakat Madura)", Jurnal Karsa vol. XI No. 1 April (2007): 15.
} 
is, at least they act in a way that makes sense. ${ }^{10}$ They have feelings in the act, there is the logic of why people act, and that is the logic of action.

Habitus concept combined with the historical method in this research is to reconstruct the compliance of coffee farmers in Sub Sumberwringin regency at Regent Amin Said Husni. The majority of Sumberwringin district ${ }^{11}$ is that the hierarchical Madurese obedient to Rato. ${ }^{12}$ Rato, in this case, means the formal leader namely Amin Said Husni which is incidentally also Madurese

\section{Results}

\section{Bondowoso Ancestor as Cultural Laboratory}

Initially, Bondowoso is a form of grove Wana Wasa as in the ancient language whose development was a result of the expansion of clearing of Besuki district. Besuki district boomed during Ronggo Regent Kiai Suroadikusumo. ${ }^{13}$ It was inseparable from the success of the development of the Port of Besuki that caused many traders and migrants seeking for works in Besuki, especially those from Madura. Likewise the migration of Javanese people, Besuki regency would gradually reach number of populations. This condition caused Regent Ronggo Kiai Suroadikusumo expanded his territory to the Southeast by disclosing forest that would be new home for the people.

His son Mas Astrotruno ${ }^{14}$ was mandated to clear the forest that would be a new shelter for the people at Besuki. Yet, in fact, the expansion of the region had a political purpose and the spread of Islam. Mas Astrotruno and his entourage head to Southern through the mountains around Arak Arak, continued until Wringin and ended up by establishing residence in the Southern area of Blindungan river. This place was known as "old district" Blindungan, located approximately 400 meters to the Northern of Bondowoso public space. The disclosing

${ }^{10}$ H. Dwi Kristanto, "Strukturalisme Levi-Strauss dalam Kajian Budaya”, dalam Teori-Teori Kebudayaan, Eds. Mudji Sutrisno dan Hendar Putranto (Yogyakarta: Penerbit Kanisius, 2005), 125.

${ }^{11}$ Badan Pusat Statistik Kabupaten Bondowoso, 2015, Kecamatan Sumberwringin dalam Angka.

${ }^{12}$ Moh. Hefni, “Bhuppa'-Bhabhu'-Ghuru-Rato, 20.

${ }^{13}$ Mashoed, Sejarah dan Budaya Bondowoso (Surabaya: Papyrus, 2004), 62.

${ }^{14}$ Mashoed, Sejarah dan Budaya, 63. 
of the forest to be community's shelter was progressing for five years (1789-1794). ${ }^{15}$ Due to his merit, in 1808 Mas Astrotruno was raised to be Demang Blindungan with a title Abhiseka Mas Ngabehi Astrotruno. According to information from the big family of "Ki Ronggo Bondowoso" that in 1809 Raden Mas Astrotruno or Bagoes Assra was appointed as vice regent by a name Abhiseka Mas Ngabehi Kertonegoro. His residence was firstly named as Blindungan, and finally changed into Bondowoso.

The interesting part was that the number of migrants from Madura to Besuki regency were employed to clear the forest and eventually became local society. Madurese migration to Java was part of the history of the Madurese. As an illustration, in 1806 there were Madurese villages in the East Corner (better known as the Eastern Java) of Java residency; 25 villages in Pasuruan, 3 villages in Probolinggo, 22 villages in Puger and 1 village in Panarukan. ${ }^{16}$ There were two fundamental reasons namely: the Madurese migration to Java (especially in 1743) was due to the internal conflict in Pamekasan's royal family that caused a war, and the long drought in Madura caused farmers at Madura could not grow crops so that they migrated to Java to get a job. The phenomenon caused the Madurese to migrate to the region through the Port Besuki. Moreover, the Javanese migrants (especially from East Java) were drawn into Besuki region to get a better life. Both Madurese and Javanese helped Mas Astrotruno disclosing the forest and eventually inhabited the region of Bondowoso.

On the other hand, the Chinese ethnic was firstly occupying a crucial position particularly in the fields of economy and government as a result of land trading in Besuki residency either by VOC, and Raffles and Daendels. The spread of Chinese ethnic into the region Bondowoso was to expand the network of economy. Grocery stores and big agricultural market place had been mastered. In Bondowoso, there were two companies of millers in 1928. The milled rice was bought from the people, and the rice was sold for local needs and exported. ${ }^{17}$

\footnotetext{
${ }^{15}$ Moch. Jusuf Ms, Babad Bondowoso (2004), 22.

${ }^{16}$ Kuntowijoyo, Perubahan Sosial dalam Masyarakat Agraris: Madura 1850-1940 (Penerbit Mata Bangsa, 2002), 75.

17 ANRI, Memori Serah Jabatan 1921-1930 (Jawa Timur dan Tanah Kerajaan) (Yogyakarta: Gadjah Mada University Press, 1978), CXXVII.
} 
By the formation of Bondowoso that was eventually evolved into a district led by Raden Bagoes Assra, had become a big laboratory where multi-ethnic lived and expressed themselves. The culture brought by Javanese and Madurese had grown rapidly.

\section{The Emergence of Kerapan Sapi and Aduan Sapi}

Since the beginning, when Mas Astrotruno or Raden Bagoes Assra got a mandate from his father-in law to disclose the forest in the Southern district of Besuki (which in turn was named Bondowoso), his followers were mostly Madurese people. At that time, Mas Astrotruno entertained the workers with a variety of entertainments such as Aduan Burung Puyuh, Sabung Ayam, Kerapan Sapi, and Aduan Sapi. Gradually, when he had settled in a place called Bondowoso, the local entertainments had flourished in the society. The Madurese who participated Mas Astrotruno in disclosing the forest and eventually settled in Bondowoso, had brought a culture of their native region, namely Madura.

The cultures that grew in Madura society were inspired by the geographical conditions of Madura. The productivity of agricultural land in Madura was comparatively low. The result of rice field and corn was approximately only half of Java area. In Madura, 1 odor of field produced approximately 5 bears of corn, whereas in Java was 12.5 bears in average. ${ }^{18}$ The minimum of food was inevitable, although the consumption remained low. Because Madura's agriculture was insufficient, the commodities exchange was a key economic sector at the time. The advent of farming, fishing and manufacturing of salt was the main incomes that could generate money, as well as the expansion of labor export.

Madura was largely dependent upon the production areas of food ingredients in Java. The center-periphery relation was also reflected in the migration of people from Java to Madura which resulted the spread of Madurese to the border area. As a result, the high migration and numerous population of Madurese were at the Eastern of Java, particularly in Bondowoso. Although they settled in the Eastern area of Java, the historical and cultural ties that belonged together, had

${ }^{18}$ Kuntowijoyo, Perubahan Sosial, 90. 
remained perfection, for example Kerapan Sapi and Aduan Sapi. The cultures were advancing in the region of Bondowoso, for which the majority of the people were Madurese ethnic.

Kerapan Sapi, Aduan Sapi and other cultures brought by the Javanese migrants alike Tingkeban, Selapan, Khitanan, Ruwat, Rokat (a ceremonial term of Madurese), funerals, Sarwah (a series of ceremonies Tahlilan after 1000 or 2000 days of a dead-man), and Akikah ${ }^{19}$, had gotten a support from the first Regent of Bondowoso "Raden Bagoes Assra". These ceremonies were not shown, but celebrated by both Javanese and Madurese family when they had a need or grieving. Since the beginning, before being a regent, Raden Bagoes Assra was a grandson of Pamekasan Regent "Tumenggung Adikoro IV". By his family background, the culture of Aduan Burung Puyuh, Sabung Ayam, Kerapan Sapi, and Aduan Sapi had been a legacy in his life. The Madurese culture was presented and performed when entertaining migrants from Madura and Java who participated Raden Bagoes Assra to disclose new territory that eventually named as Bondowoso.

The Madurese culture, especially Kerapan Sapi and Aduan Sapi had become part of community in Bondowoso, and became a regular spectacle presented by the Regent Raden Bagoes Assra. The support had made Kerapan Sapi and Aduan Sapi grew rapidly and became a highly spectacle awaited by the publics.

\section{The Existence of Islamic Culture in Bondowoso}

At present time, Kerapan Sapi and Aduan Sapi have no longer an entertainment in public's life in Bondowoso. It is due to a fear of the people to retain both cultures. The performance of Kerapan Sapi and Aduan Sapi were usually accompanied by gambling, so there was a prohibition to conduct these activities, because these were contrary to the teachings of Islam.

Bondowoso, whose people were Muslims in majority, still retained Islamic cultures such as Selamatan ${ }^{20}$ Melet Kandung (Tingkeban), Selamatan Molang Are (Selapan), Tahlil, and Diba' that

\footnotetext{
${ }^{19}$ Mashoed, Sejarah dan Budaya, 107-143.

${ }^{20}$ De Graaf \& Pigeaud, Kerajaan-Kerajaan Islam di Jawa: Peralihan dari Majapahit ke Mataram, (Jakarta: Grafiti Press, 1985)
} 
were largely a cultural transformation of Java. ${ }^{21,22}$ Thus, Akikah, Khitanan, Diba', and Barzanji (derived from the Persian culture) were only the nature and origin of Islamic cultures.

Selametan culture, for the people of Bondowoso was institutionalized and was a hereditary custom. In collectivism society, custom was a major joint to foster social life. A person who violated indigenous life would be sentenced (in the form of moral sanction), namely expelled from his community. This condition caused the existence of Islamic culture in Bondowoso.

\section{The Strength of Madurese Culture in the District of Farmer Community at Sumberwringin Bondowoso}

Sumberwringin sub-district is one of 23 districts in the Bondowoso with a distance of approximately $27 \mathrm{~km}$ South-east of the district capital. District of Sumberwringin is geographically situated at an altitude of 800 meters above sea level. In north side, it is bordered by Sukosari district, Sempol district or Mount Raung in the south area, Klabang and Botolinggo in the east area, and Tlogosari Sukosari in the west area.

Sumberwringin sub-district with an area of 13.860,7 hectares consists of 1.685 hectare Land Rice; Land moor area of 1.707,6 ha; Plantation Land area of 1.265,9 ha; Land yard for building and yard around 545,4 ha; and Dry Land (including forests), and other areas of $8.656,8$ ha. The conditions of Sumberwringin's plains composed of Rice Land covering an area of 12,16\%, Land yard for building and yard 3,93\%, Land Tegal / Gardens 12,32\%, Pool 0\%, 9,13\% Plantation, other Dry Land $62,45 \%$ of the area as whole.

The majority of people who inhabit in Sumberwringin is Madurese (Muslim). ${ }^{23}$ Madurese are known to have a distinctive

\footnotetext{
${ }^{21}$ Suwardi Endraswara, Mistik Kejawen: Sinkretisme, Simbolisme, dan Sufisme dalam Budaya Spiritual Jawa (Yogyakarta: Narasi, 2006), 82.

22 Capt. R.P. Suyono, Dunia Mistik Orang Jawa (Yogyakarta: LKiS, 2007), 131.

${ }^{23}$ Thomas Hylland Eriksen, Ethnicity and Nationalism: Anthropological Perspectives (London and Boulder, Colorado: Pluto Press, 1993), 84-85.
} 
culture, unique, stereotypical, and stigmatic. ${ }^{24}$ The typical use of the term refers to the notion that the entity has the Madurese ethnic-cultural specificity that is not similar to other ethnic communities ethnography. ${ }^{25}$ The cultural specificity can be seen among others in obedience, submission, and surrender them hierarchically to four key figures in Lifes as well as in the religious praxis. The fourth figure is Buppa', Babbu', Ghuru, and Rato (father, mother, teacher, and leader of government). ${ }^{26}$ To leading figures, that compliance hierarchical of Madurese reveals his form in the social life of their culture. ${ }^{27}$

For Madurese ethnic entities (like hierarchical obedience) becomes a necessity to be actualized in daily praxis as "normative" binding. Therefore, any neglect or intentional violation is committed over the rules that lead to the perpetrators of social and cultural sanctions. The interpretation of ethnography is more tangible in the absence of opportunity and sufficient to put aside the normative rules. In a broader sense, it can be stated that the actualization of compliance is done throughout lifes. There is no right to refer to other terms except submission, obedience, and resignation to the four figures. The compliance or adherence to mother and father (Buppa' and Babbu') as the biological parents (nasabiyah) has been already clear, and recognized its necessity. Culturally, someone's obedience and submission to his parents is absolute. If not, he will get speech or rebelliousness designation upon him by society in socio-cultural environment.

In fact, in any cultural context, the obedience of children to both parents become an absolute necessity, not negotiable, and inviolable. What may be different is just the manner and form in the manifest. The absolute compliance is not constrained by anything, as the prevalence

\footnotetext{
${ }^{24}$ Latifatul Izzah, Haji Kopi: Paradoks Masyarakat Miskin Kawasan Perkebunan Kopi Kecamatan Silo Kabupaten Jember (Yogyakarta: Jogja Bangkit Publisher, 2015), 61-62.

${ }^{25}$ Hasan Alwi, Kamus Besar Bahasa Indonesia. Ed. III (Jakarta: Depdiknas RI dan Balai Pustaka, 2001), 563.

26 A. Latief Wiyata, Madura yang Patuh?; Kajian Antropologi Mengenai Budaya madura (Jakarta: CERIC-FISIP UI, 2003), 1.

${ }^{27}$ Moh. Wardi \& Ismail, "Following The Prophet Muhammad Character Through Ngabuleh Tradition in Pondok Pesantren Darul Ulum Banyuanyar Pamekasan", Jurnal El Harakah Vol. 20 No. 1 (2018): 59-60.
} 
of which is supported by genealogical factors. Subsequent consequences are relatively inevitable that if (at this moment), a person (child) is obedient to his parents, and in a time when he becomes a parent, he would also be obeyed by their children. That is one form of inherited cultural values that are disseminated. A continuous cycle that would be repeated and sustained under normal conditions, natural, and natural, unless the inheritance of values compliance experiences a rupture caused by many conditions, factors, or other extraordinary events. ${ }^{28}$ The compliance of Madurese is also against the figure of the teacher-level position as the next hierarchy. The use of the term teacher points and emphasizes on understanding Kyai or Ustadz in Pesantren. The role and function of teachers are more emphasized on morality context attributed to the eschatological life, especially in the aspects of peace and escape from the burden of suffering in nature afterlife (morality and the sacred world). Therefore, Madurese obedience to the figure of the teacher is to be a marker of culture that they may not need to doubt its validity. The cycle-generative compliance of Madurese (as a student) to the figure of teacher can be realized as child obedience to the figure I and II, the father and mother. This condition can happen, because not all Madurese do not have a chance to be a figure of teacher.

The compliance of Madurese to figure Rato (government leaders) occupies the fourth hierarchical positions. Rato is achieved by a person of any ethnic origin, but not for genealogical factors for success in reaching the status of achievement. In reality, not all Madurese is expected to or have the opportunity to achieve a position as Rato, except for 3 or 4 persons (as Regent in Madura) in 5 to 10 years of leading. Moreover, it is just done when national policies issued in the form of the Law on Regional Autonomy in 1999. Therefore, the opportunity to occupy Rato in the reality of praxis is a rare condition that is relatively difficult to achieved by the Madurese. In that context, it can be stated that throughout the life of Madurese are still in position that must be obeyed. That is subordinate hegemonic position-affecting individuals in Madura ethnic entities.

The leader of the regency government is the Regent Amin Said Husni, considered instrumental in arranging the order of public's life

${ }^{28}$ Taufiqurrahman , "Identitas Budaya Madura", Jurnal KARSA vol. XI No. 1 April (2007): 3-5. 
through the provision of the climate and the opportunity to work, to develop the field of economic opportunity, to accommodate freedom of worship, maintaining a safe atmosphere, and build together a participatory or empowerment. In the dimension of religiosity, ${ }^{29}$ the title of Rato as figure in perspective of Madurese is equated with the term Ulil Amri that is equally obliged to obey.

\section{Discussion}

\section{The Historical Process of Planting At Arabica Coffee Public Plantation}

The planting of Arabica coffee in the Ijen highlands (currently managed by PTPN XII), inspires farming communities adjacent to the area, especially Sukorejo village, Sumberwringin, and Rejoagung. The farmers in the three villages have planted Arabica coffee that is also planted by PTPN XII. As Boeke said, the economic dualism in Sumberwringin sub-district (especially Sukorejo, Sumberwringin, and Rejoagung village as parts of the "Ijen Golden Triangle" region, can coexist in harmony. The coexistence between modern production methods (PTPN XII) and traditional methods (community of coffee farmers) has existed for years. The development of the Large stateowned Plantation (PTPN XII) especially in the planting of Arabica coffee that penetrates the European market has opened the mind of the traditional sector Sumberwringin farmers in the sub-district to plant Arabica coffee plants. This awareness encouraged community coffee farmers to develop these export crops, and this development was one of the important factors that created an expansion of exchange activities in the traditional economic sector. The pioneer was John Saryan Sukardjo.

\section{John Saryan Sukardjo}

Sukorejo village, of Sumberwringin sub-district, which is about $30 \mathrm{~km}$ from the Ijen plateau managed by PTPN XII, inspired one of its farmers named John Saryan Sukardjo to plant his field with coffee plants similar to those planted by PTPN XII, the Arabica Coffee Cluster. At a

29 A. Latief Wiyata, Carok; Konflik Kekerasan dan Harga Diri Orang Madura (Yogyakarta: LkiS, 2002), 42. 
glance, if you read the name, it is definitely not an authentic Indonesian or maybe someone who tries to add their first name "John" to look like an Indonesian proper name. However, when we communicated with an Arabica coffee farmer in Sukorejo village named John Saryan Sukardjo, it was truly a Dutch-Indonesian mulatto. The mulatto was obtained from his grandmother named Wasimah who was a "Nyai" from one of the Dutch person named Verteegh who rented land in Sumberwringin Subdistrict in the Dutch colonial period. At a glance, looking at his face is indeed quite different from the farming community in Sukorejo Village in general.

John Saryan Sukardjo deserved the nickname as a figure of Arabica coffee in Bondowoso regency. This was inseparable from his efforts to force the farmers to plant Arabica Coffee, as well as a pioneer of Arabica coffee planting as planted by PTPN XII.

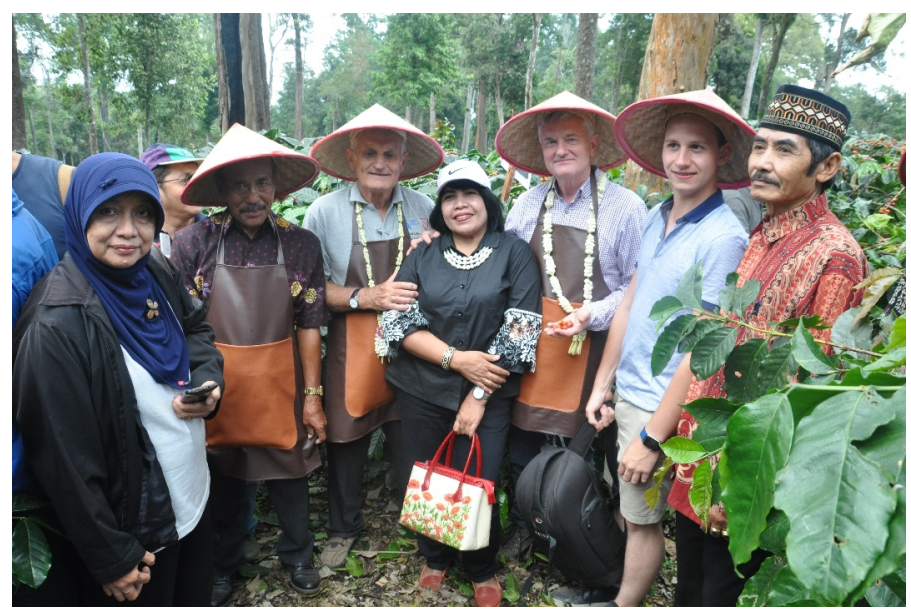

Fig. 1 John Saryan Sukardjo with the Chief of Research Team

(Research Documentation)

Popkin $^{30}$ in his theory of Political Economy explained that not all farmers who are in the subsistence crisis are resisting. This means that farmers who are in a subsistence crisis due to the penetration of

\footnotetext{
${ }^{30}$ Samuel, L.Popkin, The Rational Peasant, The Political Economy of Rural Society in Vietnam

(Berkeley-Los Angeles-London: University of California Press, 1978), 10.
} 
capital have resisted and some have not resisted, even though they have experienced a subsistence crisis. Therefore, the decision to fight or not, for farmers who were in a subsistence crisis, was not because of subsistence itself. However, the decision to fight was based on the rational calculations of the farmers. In the subsistence crush, came the ideas of a farmer named Sukardjo to plant Arabica Coffee plants as planted by PTPN XII. He also formed farmer groups as a form of resistance to PTPN XII. The farmer group led by Sukardjo was supported by Bondowoso Regent Amin Said Husni.

\section{The Support from Bondowoso Regent}

The efforts of Bondowoso regent, Amin Said Husni, to prosper his coffee farmers by planting an Arabica Coffee Cluster was worth huge appreciation. The Arabica coffee cluster was more expensive than Robusta coffee. In 2011 the $M o U$ was established with 7 parties in order to improve the yield of coffee plantations. The 7 parties included Dishutbun (A department of forestry and plantation affairs) (in 2017 merged with the Agriculture Service) Bondowoso, Bank Indonesia, Bank Jatim, Research Center for Koka, Perhutani, Apeki and Indokom as exporters. Regent Amin Said Husni tried to work together with Perhutani to increase the area of people's coffee land, in collaboration with Bank of Indonesia (BI) to help establish a Yield-Processing Unit (UPH). For sure, the whole endeavor was conducted in collaboration with Bank Jatim to help capitalize coffee farmers, the Research Center Jember to train and foster coffee farmers in the planting and processing of coffee, and coffee exporters Indokom (Ltd.). These efforts succeeded in lifting the economy of coffee farmers. To help accompany coffee farmers, the Regent assigned an Agriculture Service. The agricultural office formed a farmer group of farmer groups to give direction and approval from the Ministry for coffee farmers. There were 44 coffee farmer groups in Bondowoso regency with 24 downstream products in the form of coffee powder production. The Regent also formed the Bondowoso branch of the Indonesian Coffee Farmers Association (APEKI) to protect coffee farmers in selling their coffee production. 


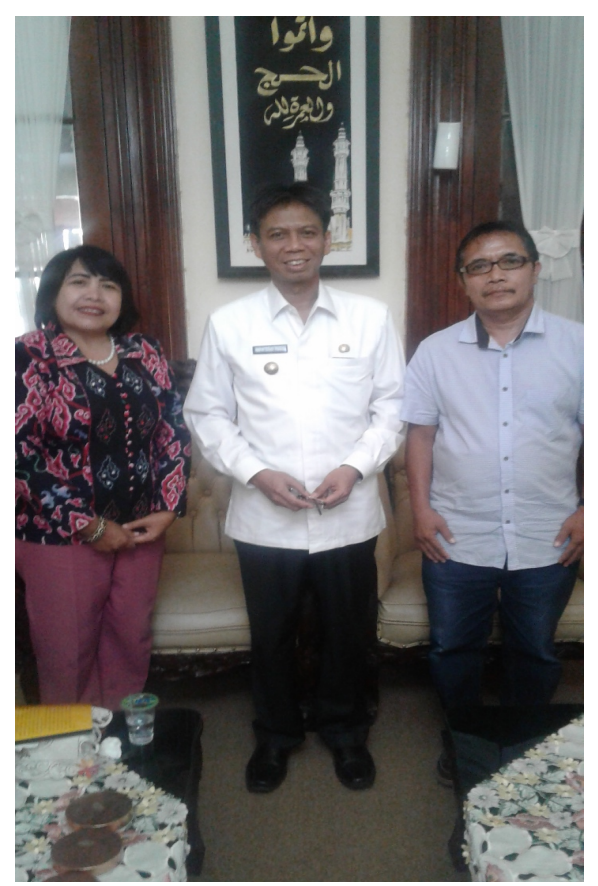

Fig. 2 Bondowoso Regent, Amin Said Husni, (white shirt) with Chief of Research Team and Member (Research Documentations)

\section{Counter Product to Public Coffee}

The intelligence of community coffee farmers in Sukorejo village, Sumberwringin sub-district, was pioneered by farmers named Jhon Saryan Soekardjo to plant Arabica coffee plants. This competence was able to emulate the superior products of large plantation companies (PTPN XII) that controlled the Ijen plateau as part of the "Ijen Golden Triangle" Bondowoso regency. Jhon Saryan Soekardjo's efforts to carry out reforms in order to improve the economy of his family and coffee farmers generally paid off. Of course, through a very long process. Finally, Soekardjo's efforts were supported by Bondowoso Regent Amin Said Husni who followed up by holding an MoU with 7 parties. Collaboration with various parties aimed to improve the processing, provision of infrastructure such as warehouses and laundering, 
assistance with processing equipment and trade procedures. Each of these parties had their role. For instance, Coffee and Cocoa Research Center provided the transfer of knowledge on standardized coffee beans processing, and Bank of Indonesia provided pipeline funding for the washing process. On the other hand, Bank Jatim provided financial assistance for the provision of warehousing and processing equipment. Indocom (Ltd.) acted as a direct buyer of the results of processing coffee beans from a group of farmers so as to shorten the trade chain. Jhon Saryan Soekardjo's efforts could eventually be enjoyed by all farmers in Bondowoso regency, with the Standard Operating Procedure (SOP) for Processing Arabica Bondowoso Coffee.

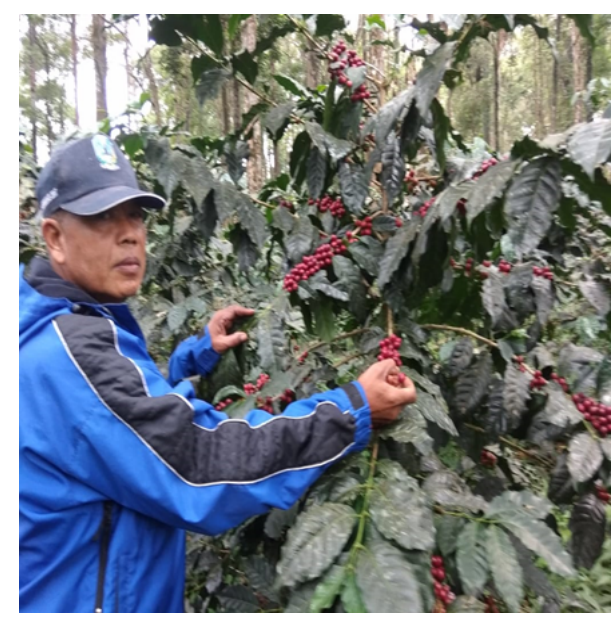

Fig. 3 Arabica Coffee Ready for Harvest (Research Documentations)

\section{The Birth of Farmer Group: An Endeavor to Reach European Market}

Boeke believes that the development of large plantations is related to the possibility of earning additional income by planting export crops. This awareness is encouraged to develop export crops and activities in the traditional economic sector. The success of the Big Plantation (PTPN XII) has inspired community coffee farmers in 
Sukorejo Village, Rejo Agung Village and Sumberwringin to form farmer groups. With the formation of farmer groups, farmers from those three villages can progress together. Even the result was beyond their expectation as the Arabica coffee farmers who involve in some of the Arabica coffee groups was successful to enter the European market, in this case Swiss.

\section{Branded Java Ijen - Raung}

As Boeke said, the development of large plantations has opened the eyes of traditional sector farmers about the possibility of earning additional income by planting export crops. This awareness encouraged them to develop export crops (coffee), and this development was one of the important factors that created an expansion of exchange activities in the traditional economic sector. The efforts made by community coffee farmers were not only from upstream but downstream, namely making coffee powder. Manufacture of ground coffee with branded Java IjenRaung with various product packaging both Arabica coffee and Robusta coffee. This effort was carried out by farmers with the assistance of Bondowoso Regent Amin Said Husni to be able to compete with Arabica coffee products owned by PTPN XII. Some packages of both Arabica coffee and Robusta coffee from farmer groups in Sumberwringin Village, Rejoagung Village and Sukorejo Village, among others:

1. Rooster brand Packaging (Wringin Source)

2. Starling brand Packaging (Wringin Source)

3. Kepodang brand (Rejo Agung)

4. Coffee Bon brand Packaging (Rejo Agung)

5. Mat Coffee brand Packaging (Sukorejo)

6. Sahabat Tiga Bintang brand Packaging (Sukorejo)

7. Twin Mountain brand Packaging (Sukorejo)

That effort was also in order to increase regional and its farmers' income. This evident is proved in the Regent Amin Said Husni's work program which is implemented in the RPJM, especially in the agriculture sector for the plantation sector. The productivity target of 
coffee plantations in 2015 was 0.08 tons per hectare, while in 2017 it increased to 1 ton per hectare.

\section{The Downstream Product of Coffee Farmers Group}

Coffee products from coffee farmers Bondowoso is not only upstream, but work up to the position downstream among other things until the process of making coffee powder. However, not all groups of farmers produce a coffee powder. Some groups of farmers that sell coffee powder require more extended period to get fresh money, because in the production process (in particular), harvesting coffee lawn and care requires much workforce and are associated with funding to pay for the labor. The huge funds in the production process cause many coffee farmers who sell in the form of $\mathrm{Hs}$ Basah or Berasan. Nevertheless, there is also a group of farmers who processes the coffee powder. Usually, the head of the farming group does not have extensive coffee plantations or even do not have the land, because it was sold for their survival. Through processing up to the coffee powder, the result is higher than its sale in the form of Hs Basah or Berasan. However, the time required in the sale of coffee powder takes a long time when the farmer group does not have a relationship with the merchants outside Bondowoso.

The followings are farmers who process up into the coffee powder. Some of them are headed by John Saryan Soekardjo, Muali, Mathosen, Harnimo, and Heru.

1. Naga Coffee Arabika; belongs to Amirudin from Usaha Tani I group.

2. Gunung Kembar; belongs to John Saryan Soekardjo from Usaha Tani II group. 


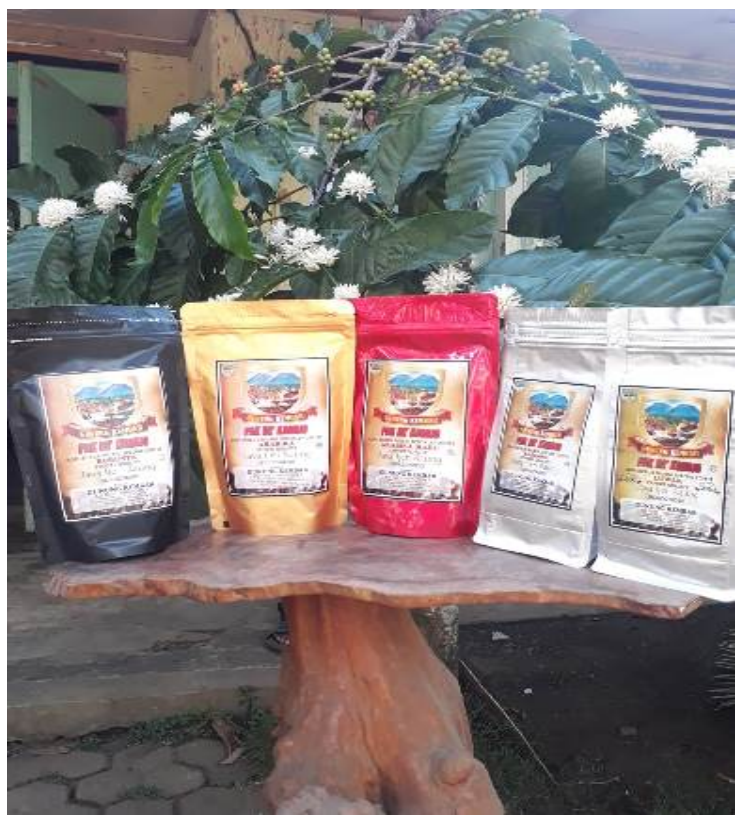

Fig. 4 Product of John Saryan Soekardjo (Research Documentation)

3. Coffee Agung; belongs to Suheri from Usaha Tani III.

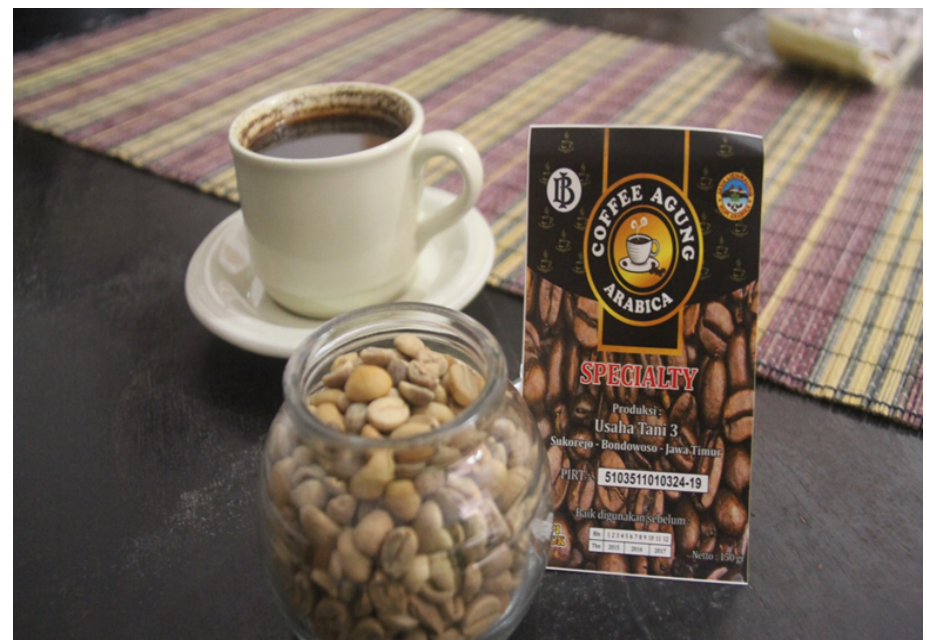

Fig. 5 Product of Suheri (Research Documentation)

Copyright (c) 2019 by Karsa. All Right Reserved DOI: 10.19105/karsa.v27i1.2152 
4. Rimpang Jahe; belongs to Subaili from Usaha Tani IV group.

5. Java Raung; belongs to H, Sumarhum from Usaha Tani V group.

6. Kijang; belongs to Tohari from Usaha Tani VI group.

7. Agung Coffee; belongs to Nanang Yuliharjo from Usaha Tani VIII group.

8. Pikopi; belongs to H. Er from Usaha Tani X group.

9. Sahabat Tiga Bintang, Dua Tangkai Bunga Mawar; belongs to Muali from Usaha Tani XI group.

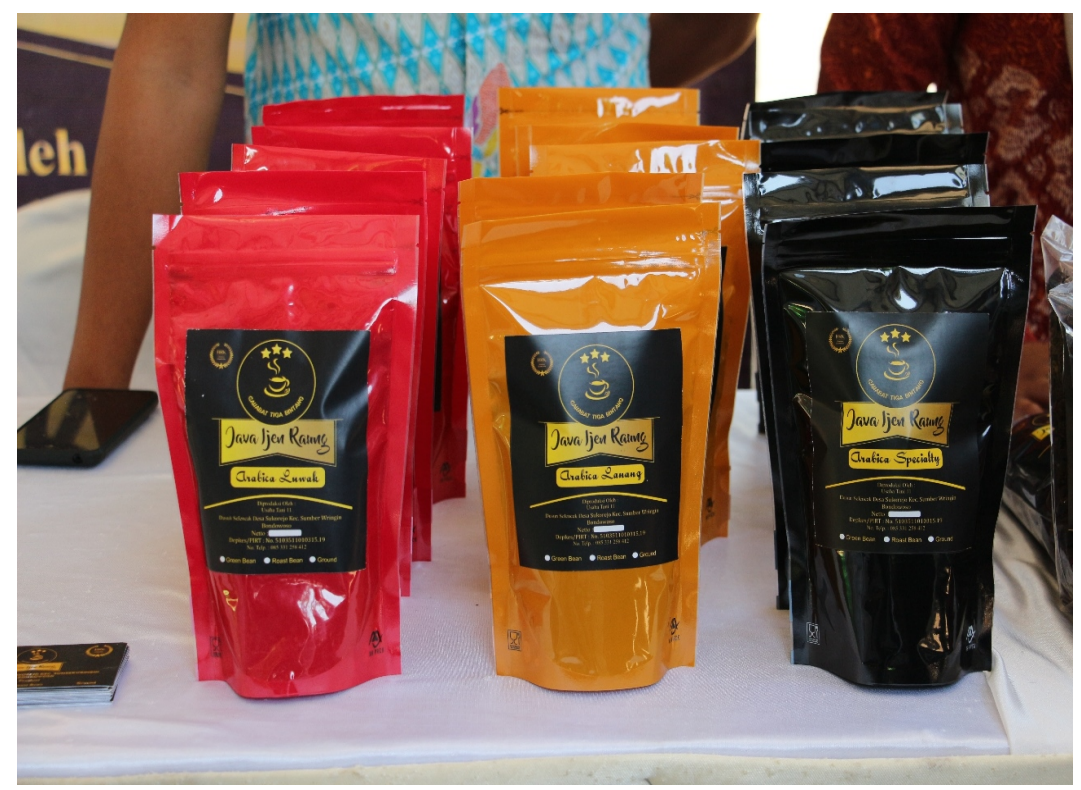

Fig. 6 Product of Muali (Research Documentation)

10. Marino; belongs to Nur Jumali from Sumber Karya I. 
11. Singo Raung; belongs to Untung from Sumber Karya II group.

12. Raja; belongs to Erwin Ardiansyah from Sumber Karya IV group.

13. Matt Coffee; belongs to Mathosen from Tani Maju I group.

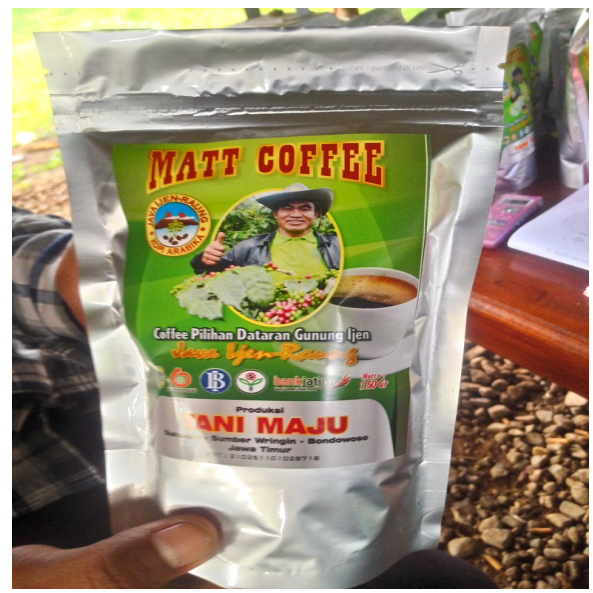

Fig. 7 Product of Mathosen (Research Documentation)

14. Kepodang Mas; belongs to Harnimo from Tani Maju III group. 


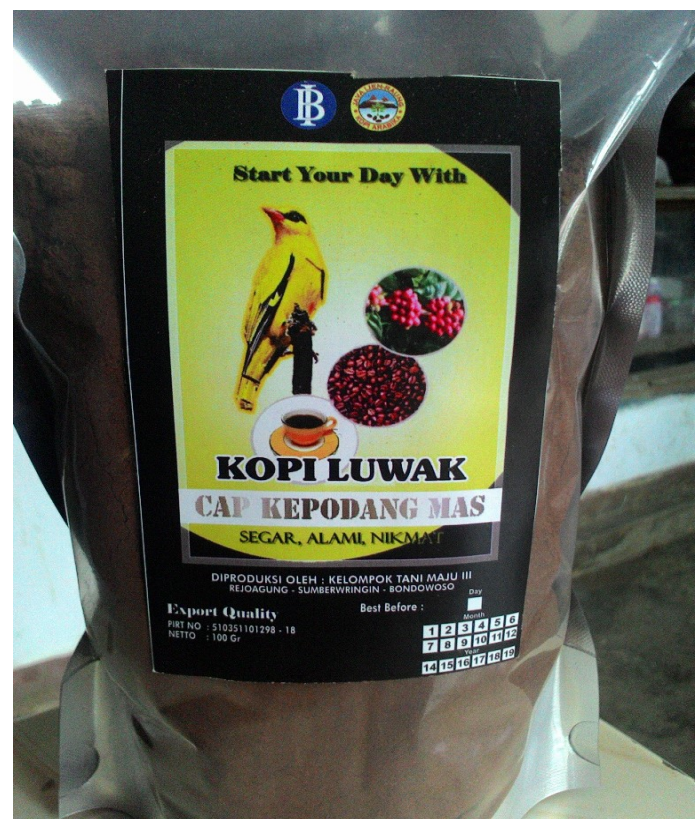

Fig. 8 Product of Harnimo (Research Documentation)

15. Kenari; belongs to Mr. Dita from Harapan Makmur II group.

16. Bintang 3; belongs to Rahmad from Harapan Makmur IV group.

17. Raung Tutul; belongs to Sahlan from Harapan Makmur V group.

18. Bondowoso Coffee; belongs to Heru Setiowibowo from Harapan Makmur VI group. 


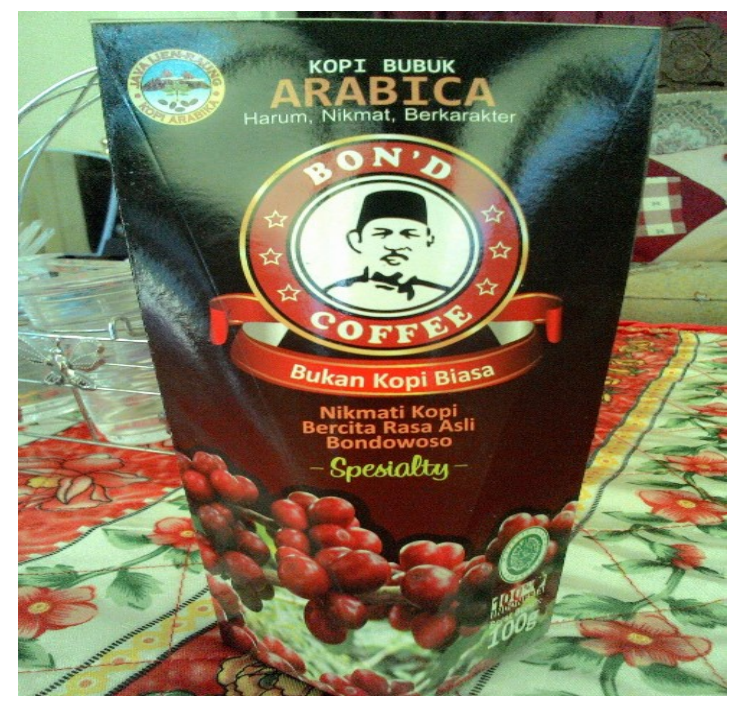

Fig. 9 Product of Heru (Research Documentation)

19. Rajawali; belongs to Bambang Sriono from Tunas Harapan group.

20. Nuri; belongs to Eko Sudarsono from Tunas Harapan II group

21. Jalak; belongs to Rustam from Darungan Jaya group.

22. Kelapa Muda (Robusta); belongs to Mr. Cicik from Pulo Agung Jaya group (Robusta).

23. Jago; belongs to Bahriman.

24. Dako Yulie; belongs to Suyitno as chief of cooperation. 


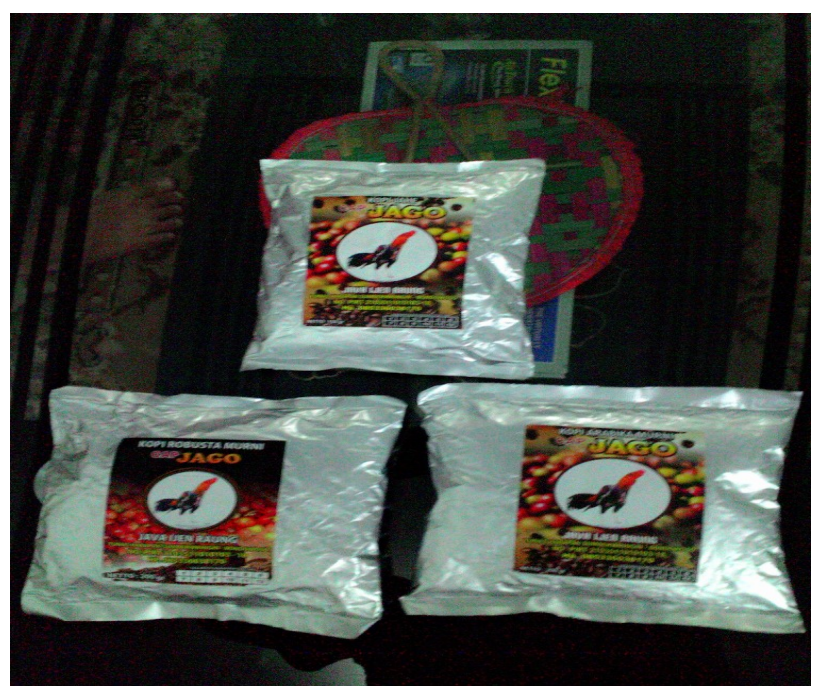

Fig. 10 Product of Bahriman (Research Documentation)

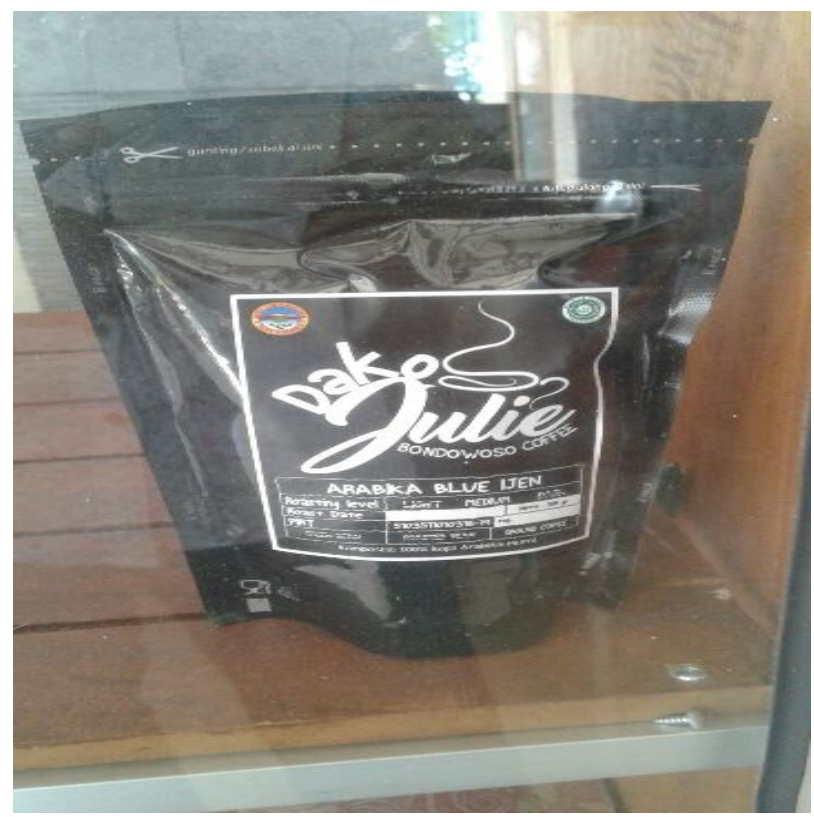

Fig. 11 Product of Chief of Cooperation Suyitno (Research Documentation)

Copyright (c) 2019 by Karsa. All Right Reserved DOI: $10.19105 /$ karsa.v27i1.2152 


\section{Conclusion}

Base on those description, the compliance with the district people's in coffee farming communities at Sumberwringin regency has proven existing, because the majority of the populations are Madurese. Madurese is known as an obedient community in carrying out the teachings of Islam. Madurese can be said closely synonymous with Islam, though not all Madurese are Muslim. Thus, as a religion of Madurese, Islam is not not only served as a reference for social behaviour in public life. However, Islam is an element of ethnic identity marker of Madurese.

The cultural specificity of Madurese is seen among others in obedience, submission, and surrender them hierarchically to four key figures in lifes, more so in the religious praxis. The fourth figure is Buppa', Babbu, Master, and Rato (father, mother, teacher, and leader of government). To leading figures, that hierarchical compliance of Madurese reveal his form in the social and cultural life of their praxis.

Moreover, the culture attached to Madurese, especially in Sub Sumberwringin Bondowoso, facilitate Regent Amin Said Husni releases his policies for the promotion of Bondowoso. The emergence of figure John Saryan Sukardjonot is able to mobilize people's coffee farming communities to switch from Robusta coffee plants to the Arabica coffee. However, the adherence to figure Rato in Madurese community (government leaders) can be proven when the Regent Amin Said Husni instructs coffee farmers to switch the cultivation of Robusta coffee to Arabika coffee. The coffee farmers are people who believe that what is commanded by the Regent must be complied with and implemented.

The compliance of coffee farming communities is incidentally Madurese that has a positive impact in their lives. This revenue increases coffee farming communities, because the selling price of Arabica coffee is higher than Robusta coffee. The Regent Amin Said Husni is Madurese who is religious, so that policies in favour are the interests of society. The efforts made by the Regent Amin Said Husni for coffee farmers in Bondowoso are: (1) cooperate with seven parties (Bank Indonesia, Bank JATIM, Perhutani, APEKI, Center Koka Jember, PT Indokom, and the Department of Agriculture), (2) choosing cluster Arabica coffee to rival products PTPN XII that hire Ijen plateau, (3) encourage Arabica coffee products produced by the coffee farmers 
for export to European countries, (4) fight for geographical indications for coffee products branded with the release of Java Ijen - Raung, and (5) downstream products of Arabica coffee farmers in Bondowoso. Under the leadership of Regent Amin Said Husni, the regency becomes Arabica coffee producing regions demanded by Indonesians and European.

\section{Acknowledgment}

The author would like to thank to promoter and co-promoter for their patients and contributions within this manuscript establishment to achieve doctoral degree in History $(\mathrm{PhD})$. The author also would like to thank to Mr. Amin Said Husni as the regent of Bondowoso who had given an opportunity for the author to conduct an interview on the researched topic. This article is a part of the author ${ }^{\text {res }}$ dissertation entitled "Coffee Plantation: Privatization of Bondowoso Region in the Colonial Era 1894-1930".

\section{Bibliography}

Alwi, Hasan. Kamus Besar Bahasa Indonesia. Ed. III. Jakarta: Depdiknas RI dan Balai Pustaka. 2001.

ANRI. Memori Serah Jabatan 1921-1930 (Jawa Timur dan Tanah Kerajaan). Yogyakarta: Gadjah Mada University Press, 1978.

Badan Pusat Statistik Kabupaten Bondowoso. Kabupaten Bondowoso dalam Angka., 2015.

Badan Pusat Statistik. Kabupaten Bondowoso. Kecamatan Sumberwringin dalam Angka, 2015.

De Graaf, HJ \& TH.G.TH Pigeaud. Kerajaan-Kerajaan Islam di Jawa: Peralihan Dari Majapahit Ke Mataram. Jakarta: Grafiti Press, 1985.

Dwi Kristanto, H. "Strukturalisme Levi-Strauss dalam Kajian Budaya". dalam Teori-Teori Kebudayaan, Eds. Mudji Sutrisno dan Hendar Putranto, Yogyakarta: Penerbit Kanisius, 2005.

Eriksen, Thomas Hylland. Ethnicity and Nationalism: Anthropological Perspectives. London and Boulder, Colorado: Pluto Press, 1993. Gottschalk, Louis. Mengerti Sejarah, Terjemahan Nugroho Notosusanto. Jakarta: UI Press, 1993. 
Izzah, Latifatul. Haji Kopi: Paradoks Masyarakat Miskin Kawasan Perkebunan Kopi Kecamatan Silo Kabupaten Jember. Yogyakarta: Jogja Bangkit Publisher, 2015.

Izzah, Latifatul and Hairus Salikin. "Feudal Culture in the Ijen Highlands' Poor Society", Jurnal Karsa vol. 24 No. 2, Desember (2016): 174.

Izzah, Latifatul. Dataran Tinggi Ijen: Potongan Tanah Surga untuk Java Coffee. Yogyakarta: Jogja Bangkit Publisher, 2016.

Izzah, Latifatul, dkk., Cluster Kopi Arabika: Produk Primadona Petani Kopi Rakyat Bondowoso. Yogyakarta: Best Publisher, 2018.

Kuntowijoyo. Perubahan Sosial dalam Masyarakat Agraris: Madura 1850-1940. Penerbit Mata Bangsa, 2002.

L. Popkin, Samuel. The Rational Peasant, The Political Economy of Rural Society in Vietnam. Berkeley-Los Angeles-London: University of California Press, 1978.

Mashoed. Sejarah dan Budaya Bondowoso. Surabaya: Papyrus. 2004.

Hefni, Moh. 'Bhuppa'-Bhabhu'-Ghuru-Rato (Studi Konstruktivisme Strukturalis tentang Hierarkhi Kepatuhan dalam Budaya Masyarakat Madura)", Jurnal Karsa vol. XI No. 1 April (2007): 15.

Jusuf M.S., Moch. (trans.) Babad Bondowoso. Unpublished. Manuscript, available and owned by Authors since 2004.

Wardi, Moh. \& Ismail, "Following The Prophet Muhammad Character Through Ngabuleh Tradition in Pondok Pesantren Darul Ulum Banyuanyar Pamekasan”, Jurnal El Harakah Vol. 20 No. 1 (2018): 59-60.

Profil Desa dan Kelurahan Kabupaten Bondowoso. Potensi Desa dan Kelurahan Desa Sukorejo Kecamatan Sumberwringin, 2015.

Smith, Philip. Cultural Theory: An Introduction. Oxford \& Massachusetts: Blackwell Publishers, 2001.

Endraswara, Suwardi. Mistik Kejawen: Sinkretisme, Simbolisme, dan Sufisme dalam Budaya Spiritual Jawa. Yogyakarta: Narasi, 2006.

Suyono, Capt, R.P. Dunia Mistik Orang Jawa. Yogyakarta: LKiS, 2007. Taufiqurrahman, "Identitas Budaya Madura", Jurnal KARSA vol. XI No. 1 April (2007): 3-5. 
The Compliance-Based Coffee Growers of Bondowoso on Regent Amin Said Husni in the Culture of Madurese Society

Wiyata, A.Latief. Madura yang Patuh?; Kajian Antropologi Mengenai Budaya Madura. Jakarta: CERIC-FISIP UI, 2003.

Carok; Konflik Kekerasan dan Harga Diri Orang Madura. Yogyakarta: LKiS, 2002. 